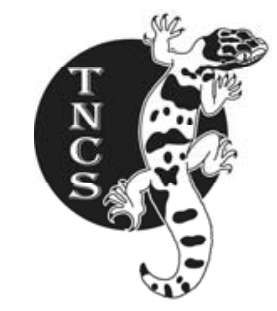

\section{Hemidactylus parvimaculatus Deraniyagala, 1953 (Reptilia: Gekkonidae) feeds on Ramanella variegata (Stoliczka, 1872) (Amphibia: Microhylidae) in Sri Lanka}

The gecko genus Hemidactylus comprises seven species in Sri Lanka (Bauer et al., 2010; Deraniyagala, 1953; Somaweera \& Somaweera, 2009) and is thus the second largest gecko genus of the island. Here we record first observation of amphibian predation by $H$. parvimaculatus in an anthropogenic habitat in Sri Lanka.

The observations were made in a human habitation at Puttalam (altitude $10 \mathrm{~m}, 8^{\circ} 01^{\prime} 05.06^{\prime} \mathrm{N}, 79^{\circ} 50^{\prime}$ 23.76” E) approximately $1 \mathrm{~km}$ away from Puttalam City in Puttalam District in Northwestern Province of Sri Lanka. Observations were made by naked eye, about $2 \mathrm{~m}$ away from the gecko from 18:40 hr to $19: 00 \mathrm{hr}$. No disturbances were made to the animal during the time of observation. All measurements were taken to the nearest $0.1 \mathrm{~mm}$ using dial calipers. A fully grown mature male Hemidactylus parvimaculatus (SVL $55.6 \mathrm{~mm}$, TL $68.2 \mathrm{~mm}$ ) was observed on $28^{\text {th }}$ April 2009 at about 18:40 hr. The entire day had been rainy. The gecko was lying on a wall, $180 \mathrm{~cm}$ above the ground level. At this time three Ramanella variegata microhylid frogs were also observed about $40 \mathrm{~cm}$ away from it. The gecko moved slowly towards the frogs and suddenly jumped forward and caught a frog's head by its mouth at about 18:52 hr. However the other frogs did not show any reaction to this and remained adherent to the wall. Then the gecko dashed the prey twice on the wall and repeated this action thrice. It then swallowed the prey at about 18:58 hr. After two minutes the gecko moved away.

The estimated prey size (SVL of the frog) of this gecko was $15 \mathrm{~mm}$. Hence, the gecko (SVL 55.6 $\mathrm{mm}$ ) can easily prey on this species. Some geckoes regurgitate prey when it is too large to swallow or if they feel uncomfortable after ingestion. However in this situation this gecko took the prey easily and exhibited apparent experience with this prey type.
Polypedatus maculates and Hemidactylus frenatus are also sympatric in this microhabitat.

In other predatory observations of geckos we did not observe such dashing behaviours to kill their prey. Sometimes geckos may use such additional methods to kill large prey, especially vertebrates, which, if not killed properly might make ingestion difficult or uncomfortable.

\section{Acknowledgements}

The authors would like to thank Mr. Saman Navaratne (IUCN - Sri Lanka) for the help during the observation.

\section{Literature Cited}

Bauer, A. M., T. R. Jackmann, E. Greenbaum, A. de Silva, V. B. Giri and I. Das. 2010. Molecular evidence for taxonomic status of Hemidactylus brookii group taxa (Reptilia: Gekkonidae). Herpetological Journal, 20: 129-138.

Somaweera, R. and N. Somaweera. 2009. Lizards of Sri Lanka: A colour guide with field keys. Edition Chimaira, Frankfurt am Main, Germany: 303.

Deraniyagala, P. E. P., 1953. A Colored Atlas of some vertebrates from Ceylon, Tetrapod Reptilia. Vol-2. National Museums of Sri Lanka, Colombo: 101.

Submitted: 07 October 2010, Accepted: 22 January 2011 Sectional Editor: Aaron Bauer

D. M. S. Suranjan Karunarathna ${ }^{1}$ A. A. Thasun Amarasinghe ${ }^{2}$

${ }^{1}$ Nature Exploration \& Education Team, B-1 / G-6, Soysapura, Moratuwa 10400, Sri Lanka E-mail: dmsameera@gmail.com

Taprobanica Nature Conservation Society, 146, Kendalanda, Homagama, Sri Lanka E-mail: thasun.taprobanica@gmail.com 